\title{
Ortaöğretim Öğrencilerinin Yaşam Doyumu ve Şükran Düzeylerini Arttırmaya Yönelik Bir Müdahale Programının Etkililiğinin İncelenmesi
}

Investigation of the Effectiveness of an Intervention Program for Increasing High School Students' Life Satisfaction and Gratitude Levels

\section{Mehmet Sıddık VANGÖLÜ[1] Ferhat KARDAŞ[2]}

Başvuru Tarihi:28 Aralık 2021

Kabul Tarihi:02 Şubat 2022

Önleyici ve gelişimsel müdahale programları, okul psikolojik danışma ve rehberlik çalışmalarının önemli bir parçasıdır. Pozitif psikoloji temelli müdahale programları bireylerin iyi oluş düzeyleri ve yaşam doyumlarını arttırmayı, kişisel potansiyellerini geliştirmeyi amaçlamaktadır. Bu araştırmanın amacı pozitif psikoloji temelli olarak hazırlanmış bir müdahale programının ergenlerin yaşam doyumu ve şükran düzeyi üzerindeki etkililiğinin incelenmesidir. Araştırmada ön-test, son-test, kontrol gruplu yarı deneysel desen kullanılmıştır. Araştırma liseye devam eden toplam 24 ergen ile gerçekleştirilmiştir. Müdahale programı 90 dakikalık 6 oturumda gerçekleșmiştir. Verilerin toplanmasında Yaşam Doyumu Ölçeği ve Şükran Ölçeği kullanılmıştır. Deney grubuna altı haftalık müdahale programı uygulanırken kontrol grubuna herhangi bir uygulama yapılmamıștır. Verilerin analizinde Mann-Whitney U-Testi ve Wilcoxon İşaretli Sıralar Testi kullanılmıştır. Araștırma sonuçlarına göre deney grubunda yer alan öğrencilerin yaşam doyumu düzeylerinin kontrol grubunda yer alan öğrencilere göre anlamlı bir şekilde yükseldiği bulunurken şükran düzeyinde meydana gelen yükselişin istatiksel olarak anlamlı olmadığı bulunmuştur.

Anahtar Kelimeler: pozitif psikoloji, yaşam doyumu, şükran, öğrenci

Preventive and developmental intervention programs are an important part of school counseling and guidance work. Positive psychology-based intervention programs aim to increase individuals' well-being and life satisfaction, and to develop their personal potential.The aim of this study is to examine the effectiveness of the intervention program prepared according to the principles of positive psychology on life satisfaction and gratitude. In this study, a semi-experimental design with pretest posttest control group has been used. The sample has consisted of 24 (12 for the experimental group and 12 for the control group) adolescent who are high school students. The intervention program has taken place in 6 sessions of 90 minutes. Life Satisfaction Scale and Gratitude Scale has been used to collect data. While a six-week intervention program has been applied to the experimental group, no application has been made to the control group. Mann-Whitney U-Test and Wilcoxon Signed-Rank Test has been used to analyze the data. According to the results of the study, it has been found that the life satisfaction levels of the students in the experimental group has increased significantly compared to the students in the control group, while the increase in the level of gratitude has not been statistically significant.

Keywords: positive psychology, life satisfaction, gratitude, student

Vangölü, M. S., \& Kardaş, F. (2022). Ortaöğretim öğrencilerinin yaşam doyumu ve şükran düzeylerini arttırmaya yönelik bir müdahale programının etkililiğinin incelenmesi. Humanistic Perspective, 4 (1), 11-27. https://doi.org/10.47793/hp.1045601

\footnotetext{
[1] Doktora Öğrencisi | Van Yüzüncü Yıl Üniversitesi | Eğitim Fakültesi | Rehberlik ve Psikolojik Danışmanlık | Van | Türkiye | 0RCID: 0000-0002-8312-9795 | mehmetsvngl_13@hotmail.com [2] Dr. Öğr. Üyesi| Van Yüzüncü Yıl Üniversitesi | Eğitim Fakültesi | Rehberlik ve Psikolojik Danıșmanlık | Van | Türkiye | ORCID: 0000-0003-3386-3956
} 


\section{GíRİs}

- nemli bir gelişim ortamı olarak okul öğrencilerin hem zamanlarının çoğunu geçirdikleri (Özdemir-Sağkal, 2013) hem de bilişsel, sosyal ve duygusal becerileri kazandıkları önemli bir yerdir (Güngör, 2017). Okulların temel amacı bireyleri içinde yaşadıkları topluma ve dünyaya katkı sunacak kişiler olarak yetiştirmektir. Bu çerçevede öğrencilere akademik becerilerin kazandırılmasının ve öğretim sürecinin yanında onların iyilik halini arttıracak karakter güçlerinin kazandırılması önemli olup bu kapsamlı yaklaşımın öğrencileri yaşama daha iyi hazırlaması beklenmektedir (Ergüner-Tekinalp, 2020). Geleneksel psikolojinin sorun odaklı bakıș açısına karşın (Şirin-Ulaş, 2015), görece yeni bir yaklaşım olan pozitif psikoloji bireylerin olumlu yönlerine odaklanmanın onların yaşam kalitesini geliştireceği ve potansiyellerini daha etkili şekilde geliştireceğini savunur (Güngör, 2017). Bu alanda önemli çalışmaları bulunan Seligman ve Csikszentmihalyi (2000) eğitimcilerin ve psikologların insanların iyi oluş düzeylerini arttırmaya dönük çalışmalar yapmaları gerektiğini savunurlar.

Pozitif psikoloji yaklaşımıyla birlikte mutluluk kavramına yönelik araştırmaların sayısı hızla artmaya başlamış ve mutluluk konusu, iyi oluş kavramı çerçevesinde yaygın şekilde ele alınmaya başlanmıştır. Buna göre alanyazında iyi oluş konusu psikolojik iyi oluş ve öznel iyi oluş şeklinde kavramsallaştırılmaktadır (Kardaş ve Yalçın, 2020). Öznel iyi oluş; bireyin daha fazla hoşa giden olumlu deneyimler yaşamaları, daha az istenmeyen deneyim yaşamaları, yaşamdan zevk ve doyum almaları ve daha az acı çekmeleri olarak ele alınmaktadır (Diener, 2000). Buna göre öznel iyi oluş; yaşam doyumunun yüksek olması, pozitif duygulanımın yüksek olması ve negatif duygulanımın düşük olması çerçevesinde ele alınırken, psikolojik iyi oluş temelde insani potansiyeli gerçekleştirmekle ilgilidir (Hefferon ve Boniwell, 2014). Bu çerçevede yaşam doyumu kavramı da öznel iyi oluşun bileşenlerinden biri olarak ele alınmaktadır.

Öznel iyi oluşu oluşturan bileşenlerden biri olan yaşam doyumu (Dağlı ve Baysal, 2016) belirli bir duruma ilişkin doyumla sınırlı olmayıp tüm yaşantıya ilişkin doyumu ve yaşamın genel olarak bilişsel değerlendirmesini ifade etmektedir (Diener vd., 1999). Diğer bir ifade ile yaşam doyumu, bireyin kendi yaşamıyla ilgili genel yargı ve değerlendirmeleridir (Çivitçi, 2012). Yaşam doyumu bireyin sahip olduğu; cinsiyet, eğitim durumu, sosyal destek unsurları, evlilik, yaş, sağlık durumu, işi, geliri gibi faktörlerden etkilenmektedir (Özgür vd., 2010). Ergenler arasında da olumlu gelişim için önemli görülen kavramlardan biri olan yaşam doyumu, ruh sağlığı ve yaşam kalitesinin önemli bir unsurudur (Proctor vd., 2009). Bu kapsamda yapılan araștırmalarda ergenlerde yaşam doyumunun çeşitli psikolojik, davranışsal ve sosyal değiş̧kenleri olumlu etkilediği bulunmuştur (Diener vd., 2018). Alanyazın incelendiğinde yaşam doyumunun ergenlerde utangaçlık ve öz-yeterlik algısı (Erol, 2017), yalnızlık düzeyi (Türkel ve Dilmaç, 2018), internet bağımlılığı (Köse, 2016), okula bağlanma (Savi-Çakar ve Karataş, 2017) gibi değişkenler 
üzerinde etkili olduğu ortaya konulmuştur. $\mathrm{Bu}$ sonuçlar ergenlerde yaşam doyumunun yükselmesinin onların hem eğitsel de hem psiko-sosyal alanlardaki gelişimleriyle yakından ilişkili olduğunu ortaya koymaktadır.

Son yıllarda alanyazında ruh sağlığını iyileştirmede yaygın olarak kullanılan karakter güçlerinden biri de şükran kavramıdır (Kardaş ve Yalçın, 2018). Özellikle pozitif psikoloji yaklaşımının yaygınlaşmasıyla birlikte şükran duymaya yönelik müdahale çalışmalarının sayısında önemli bir artış olmuş ve şükran kavramı çeşitli değişkenlerle birlikte araştırılan kavramlardan biri haline gelmiştir (Teoman, 2015). Alanyazında şükran duyma kavramı bir duygu olarak, hayatı bir hediye şeklinde değerlendirmeye ilişkin genel bir eğilim olarak veya bir karakter gücü olarak farklı şekillerde ele alınmaktadır. Şükran duyma çok boyutlu bir kavram olarak ele alınmakta, hem anlık duygulanım boyutuyla hem de uzun süreli bir eğilim șeklinde kavramsallaştırılmaktadır. (Kardaş ve Yalçın, 2018). Bu çerçevede şükran kavramı duygu, tutum, erdem, alışkanlık, kişilik özelliği, başa çıkma yöntemi boyutlarıyla incelenmektedir (Emmons, 2009). Şükran duymanın, kendisine yapılan bir iyilik için ona yardım eden bireye yönelik minnet duygusu, elde edilen bir yarara yönelik memnuniyeti ifade eden bir duygu ve birbiriyle ilişkili olan bazı boyutlardan oluşan genel bir kişilik özelliği gibi çeşitli tanımlamaları yapılmaktadır (Kardaş ve Yalçın, 2019). Alanyazın incelemelerinde şükran kavramın çoğunlukla iyilik veya iyi oluş değiş̧kenleri ile ele alındığı görülmektedir (Teoman, 2015). Yapılan çalışmalar; şükranın gençler arasında da akademik başarı, uyum, olumlu aile ilişkileri gibi olumlu özellikleri geliştirdiği, riskli davranışlara karşı da koruyucu bir faktör olduğunu göstermektedir (Ma vd., 2013).

Froh ve arkadaşları (2008) tarafından ergenler üzerinde yapılan bir müdahale çalışmasında, deney grubunda bulunan bireylerden iki hafta süresince günlük yaşantılarında şükran duygusu hissettikleri beş şeyi not almaları istenirken kontrol grubunda yer alanlardan gündelik yaşantılarını yazmaları istenmiştir. Araştırmanın sonunda deney grubunda yer alan bireylerin yaşam doyumu ve iyimserlik düzeyinin kontrol grubunda yer alanlara göre anlamlı şekilde daha yüksek olduğu bulunmuştur. Çalışmada okulla ilgili olumlu yaşantılarını yazan öğrencilerin okul doyumu puanlarının daha yüksek olduğu belirlenmiștir. Benzer başka bir çalışmada araştırmaya katılan kişilerden günde 10-15 dakika zaman ayırıp kendilerine daha önce iyilikte bulunmuş kişilere şükran mektubu yazıp onlara iletmelerini istemişlerdir. $\mathrm{Bu}$ müdahalenin uygulandığı grupta yer alan bireylerin pozitif duygulanım düzeylerinin sadece yaptıkları şeyleri yazan kişilerden istatistiksel olarak daha anlamlı olduğu ve bu farkın sonraki iki ay boyunca devam ettiği ortaya konulmuştur (Froh vd., 2009). Bu bulgular şükran müdahalelerinin iyimserlik, pozitif duygulanım ve yaşam doyumu düzeylerini arttırdığını ortaya koymaktadır. 
Başlangıçta hastane ve toplum ruh sağlığı merkezlerinde uygulanan, davranış bozuklukları olan bireylere tanı koyma ve tedavi etme yaklaşımının ötesinde bazı önleyici nitelikte yaşam becerilerinin de kazandırılabileceği görüşüyle ortaya çıkan ve psikolojik yardımın eğitsel, gelişimsel ve önleyici yönünü vurgulayan psiko-eğitim programları, eğitim ortamlarında da yaygınlaşmaya başlamıștır. Psiko-eğitim programları her yaş grubundan bireylerde kaygl, öfke, stres, travma vb. konularda çalışılmış, bu yaklaşımın etkililiği deneysel yöntemlerle de kabul görmüştür (Çivitci, 2020). Alanyazın araştırmalarında yaşam doyumu ve şükran ile ilgili deneysel çalışmaların çok sınırlı olduğu bulunmuştur. Bu çalışma sonucunda elde edilen bulguların, eğitim alanında pozitif psikolojisi uygulamaları ile ilgili yapılan çalışmalara katkı sağlayacağı gibi okullarında gençler arasında olumlu özelliklerin gelişimi için çalışmalar hazırlayan okul psikolojik danışmanları ve öğretmenlere programlarını oluşturmada yol göstermesi beklenmektedir. Sonuç olarak bu çalışmanın amacı ortaöğretime devam eden öğrencilerinin yaşam doyumu ve şükran düzeylerini arttırmaya yönelik hazırlanmış bir müdahale programının etkililiğinin incelenmesidir.

\section{YÖNTEM}

\section{Araștırmanın Modeli}

Bu çalışma ortaöğretim öğrencilerinin şükran ve yaşam doyumu düzeylerini arttırmaya yönelik oluşturulan bir müdahale programının etkisini belirlemeyi amaçlayan yarı deneysel bir araştırmadır. Araştırmada öntest-sontest, kontrol gruplu, iki faktörlü (2x2) karışık (split-plot) desen kullanılmıştır. Gerçek deneme modellerinin gerektirdiği kontrollerin sağlanamadığı durumlarda yarı deneysel modellerden yararlanılır (Karasar, 2014). Yarı deneysel araștırmalar bir araştırmanın deneysel olmasını sağlayan iç ve dış geçerliliğin tam olarak sağlanamadığı araştırmalardır (Can, 2019).

\section{Araştırmanın Çalışma Grubu}

Araştırmanın çalışma grubu Van ili İpekyolu ilçesinde bir devlet lisesinde 11. sınıfa devam eden lise öğrencilerinden gönüllük esasına göre seçilmiştir. 11. sınıfa devam eden $(n=54)$ öğrencilere Şükran Ölçeği ve Yaşam Doyumu Ölçeği uygulanmış, yaşam doyumu ve şükran puanları dikkate alınarak her iki ölçekten alınan puanlar küçükten büyüğe doğru olacak şekilde sıralanmıştır. İlk 36 öğrenci ile görüşme yapılmıștır. Bu öğrenciler ile yapılan görüşmeden sonra 12 kişilik deney ve 12 kişilik kontrol grubu oluşturulmuştur.

\section{Veri Toplama Araçları}

Yaşam Doyumu Ölçeği (YDö). Diener ve arkadaşları (1985) tarafından geliştirilen Yaşam Doyumu Ölçeği Likert tipinde bir ölçek olup toplamda 5 madde içermektedir. Ölçek, tek boyutlu bir yapıya sahiptir. Ölçek maddelerinde "hiç katılmıyorum (1)", "katılmıyorum (2)", "kısmen 
katılmıyorum (3)", "ne katılıyorum ne katılmıyorum (4)", "kısmen katılıyorum (5)", "katılıyorum (6)", "tamamen katılıyorum (7)” şeklinde ifadeler bulunmaktadır. Ölçekte ters madde bulunmaktadır. Ölçekten alınan düşük puan düşük yaşam doyumunu, yüksek puan yaşam doyumu düzeyinin yüksekliğini ifade eder. Ölçeğin orijinal çalışmasında Cronbach Alpha iç tutarlık değeri .87 olarak hesaplanmıştır. Ölçeğin ölçüt geçerliği .82 'dir. Türkçe’ye uyarlama çalışması Köker (1991) ve Yetim (1993) tarafından yapılmış, Yetim'in (1993) çalışmasında iç tutarlık değeri .86, test-tekrar test güvenirliği ise .73 olarak bulunmuştur.

Şükran Ölçeğii. Kardaş ve Yalçın (2019) tarafından geliştirilen Şükran Ölçeği Likert tipinde 25 maddeden oluşan bir ölçme aracıdır. Maddeler "kesinlikle katılmıyorum (1)", "katılmıyorum (2)”, "kararsızım (3)”, "katılıyorum (4)", "kesinlikle katılıyorum (5)” olarak ifade edilmektedir. Ölçekten yüksek puan alınması yüksek düzeyde şükran duygusunu ifade etmektedir. Şükran ölçeği 6 alt boyuttan oluşan bir ölçektir. Bu alt boyutlar pozitif sosyal karşılaştırma, olumlu olana odaklanma, aile ve çevrenin katkılarını fark etme, mahrumiyet yerine bolluk hissi, küçük şeylere şükran duyma ve şükranı ifade etme alt boyutlarıdır. Ölçekten alınan toplam puanın iç tutarlılık katsayısı .88; alt boyutlardan pozitif sosyal karşılaştırma .73, olumlu olana odaklanma .72, aile ve çevrenin katkılarını fark etme .70, mahrumiyet yerine bolluk hissi .76, küçük şeylere şükran duyma .72 olarak bulunmuştur.

\section{Veri Toplama Süreci}

Araştırmada müdahale programı başlamadan önce öğrencilere Şükran Ölçeği ve Yaşam Doyumu Ölçeği uygulanmış ve öntest verileri toplanmıştır. Deney ve kontrol grupları oluşturulduktan sonra müdahale programı uygulanmıştır. Uygulama sonunda deney ve kontrol gruplarına ölçekler tekrar uygulanmış ve son-test verileri toplanmıştır.

\section{Verilerin Analizi}

Araştırmanın analizinde SPSS 24 programı kullanılmıştır. Araştırmadan örneklem büyüklügünün 30'dan az olmasından dolayı verilerin analizinde parametrik olmayan testler (Büyüköztürk, 2017) Mann Whitney U Testi ve Wilcoxon İşaretli Sıralar Testi kullanılmıştır.

\section{Etik Onay}

Araştırmanın yürütülmesi için Van Yüzüncü Yıl Üniversitesi Sosyal ve Beşeri Bilimleri Yayın Etik Kurulu'nun onayı alınmıştır. Çalışmaya katılan öğrenciler ve velilerinden onam alınarak çalışma yürütülmüştür.

\section{Grup Müdahalesi}

Deneysel İșlem Van ili İpekyolu ilçesinde bir devlet lisesinde araștırmacı tarafından yapılmıştır. Çalışmada 12 kişiden oluşan deney grubuna alanyazından yararlanılarak hazırlanan 
6 haftalık müdahale programı uygulanırken, kontrol grubunda bulunan öğrencilere ise herhangi bir uygulama yapılmamıştır. Müdahale programının akış süreci şöyledir:

\section{Oturum.}

a. Giriş, tanışma ve ısınma etkinliklerinin yapılması.

b. Grup kurallarının oluşturulması.

c. Çalışmanın amacının ve içeriğinin sunulması.

d. Yaşam doyumu ve şükran kavramları hakkında sunu yapılması.

e. Ödev olarak, ilham veren bir yaşam hikayesi hakkında araştırma yapılması.

Oturumun Uygulanması. Birinci oturumda grubun genel amacı ve kurallar hakkında konuşuldu. Grup üyelerinden gruptan beklentilerini ifade etmeleri istendi. Grup üyelerinin birbirlerini daha iyi tanıması için "İsmin Anlamı" egzersizi yapıldı. Daha sonra yaşam doyumu ve şükran kavramları üzerinde duruldu. Oturum sonunda grup üyelerinden kendileri için ilham veren ve onları iyi hissettiren bir yaşam hikayesi araştırmaları ve sonraki oturumda paylaşmaları konusunda ödev verildi.

\section{Oturum}

Oturumun Amacı. İlham veren bașarı hikâyelerinin paylașılması, ilham alınan yönler üzerinde konuşulması
a. Isınma egzersizi ile oturumun açılması ve önceki oturumun değerlendirilmesi.
b. İlham veren yaşam hikayelerinin tüm katılımcılar tarafından sıra ile ifade edilmesi.
c. İlham veren yaşam hikayeleri yoluyla yaşam amaçları oluşturulması.

Oturumun Uygulanması. İkinci oturumun başında ısınma egzersizi ve daha sonra önceki oturumun değerlendirmesi yapıldı. Ardından grup üyeleri için ilham veren yaşam hikayeleri konuşuldu. Bu yaşam hikayeleri yoluyla grup üyeleri ile yaşam doyumu, yaşam amacı, şükran, iyi oluş gibi kavramlar hakkında farkındalık çalışması yapıldı.

\section{Oturum.}

Oturumun Amacı. Film incelemesi yoluyla yaşam doyumu, azim ve şükran duygusunun arttırılmasi
a. Isınma egzersizi ile oturumun açllması ve önceki oturumun değerlendirilmesi.
b. Yaşam doyumu, şükran ve azim temalı film izlenmesi.
c. İzlenen filmin değerlendirilmesi. 
d. Ödev olarak başka bir film izlenmesi.

Oturumun Uygulanması. Üçüncü oturumun başında ısınma egzersizi ve önceki oturumun değerlendirmesi yapıldıktan sonra okul konferans salonunda yaşam doyumu, azim, şükran temalı film izlendi. Oturumun sonunda grup üyeleri film hakkındaki duygu ve düşüncelerini ifade ettiler. Bir sonraki oturum için film izleme ödevi verildi.

\section{Oturum.}

Oturumun Amacı. Katılımcılara kendi hayatlarından ve yakın çevrelerindeki kişilerin hayatlarından örneklerle yaşama daha olumlu bakmaları konusunda yardımcı olma.

a. Isınma egzersizi ile oturumun açılması ve önceki oturumun değerlendirilmesi.

b. Film inceleme yazılarının paylașılması

c. Geçmiş başarılar ve yakın çevredeki insanların başarı hikâyelerinin paylaşılması.

Oturumun Uygulanması. Grup üyeleri geçmişte deneyimledikleri kişisel başarıları ve yakın çevrelerinde yaşayan insanların başarıları hakkında paylaşımda bulundular. Bu paylaşımlar hakkındaki duygu ve düşünceler hakkında farkındalık oluşturuldu. Bir sonraki oturum için ödev olarak grup üyelerinden yakın çevrelerindeki kişilerin olumlu yaşam hikayeleri hakkında araştırma yapmaları istendi.

\section{Oturum.}

Oturumun Amacı. Zorluklarına rağmen hayatın güzelliklerinin ve olumlu yönlerinin fark edilmesi.

a. Isınma egzersizi ile oturumun açılması ve önceki oturumun değerlendirilmesi.

b. Çevredeki başarı hikayelerinin paylașılması.

c. Olumlu olana odaklanma ve Pozitif Sosyal Karşılaştırma

i. Hayatınızdaki olumlu yönleri düşünün.

ii. Diğer insanların hayatlarını düşünün.

iii. Hayatın kendisinin güzelliği hakkında düşünün.

Oturumun Uygulanması. Grup üyeleri tarafından bir önceki oturumun ödevi olan yakın çevredeki başarı hikayeleri hakkında hazırladıkları ödevler ve bunların bireyde uyandırdığı olumlu duygu ve düşünceler ifade edildi. Daha sonra zorluklara rağmen hayatın olumlu yönlerinin ve güzelliklerinin keşfedilmesi çalışması yapıldı. 
6. Oturum.

Oturumun Amacı. Genel değerlendirme ve grubun sonlandırılması.

a. Isınma oyunu ile oturumun açılması ve önceki oturumun değerlendirilmesi

b. “Gelecekteki En İyi Ben” etkinliğinin yapılması.

c. Oturumlar hakkında genel değerlendirme, duygu ve düşüncelerin alınması.

d. Sonlandırma etkinliği ile oturuma olumlu duygular ile veda etme.

e. Grubun sonlandirılması.

Oturumun Uygulanması. Bu oturumda “Gelecekteki En İyi Ben" uygulaması ile katılımcılara hayatlarında çok çalışıp bütün amaçlarına ulaştıklarını ve hayallerini gerçekleştirdiklerini düşünmeleri ve böyle bir hayatın nasıl bir hayat olacağını, hangi güçlü yönlerinin ön planda olduğunu düşünmeleri ve bunları yazmaları istenmiştir.

\section{BULGULAR}

Deneme öncesi deney ve kontrol gruplarının şükran ve yaşam doyumu düzeylerini gösteren betimsel istatistikler Tablo 1'de, ön test sonucunda gruplar arasında anlamlı bir farklılık olup olmadığını gösteren Man Whtiney U Testi sonucu Tablo 2'de verilmiştir.

\section{Tablo 1}

Deney ve kontrol gruplarının ön-test son-test şükran ve yaşam doyumu puanlarına ilişkin betimsel istatistikler

\begin{tabular}{lllcc}
\hline Gruplar & Ölçümler & $\mathbf{N}$ & $\overline{\boldsymbol{X}}$ & SS \\
\hline \multirow{4}{*}{ Deney Grubu } & Şükran Ön test & 12 & 94.75 & 3.14 \\
& Şükran Son test & 12 & 101.08 & 2.60 \\
& Yaşam Doyumu Ön test & 12 & 16.33 & 1.84 \\
& Yaşam Doyumu Son test & 12 & 20.66 & 2.14 \\
\hline \multirow{3}{*}{ Kontrol Grubu } & Şükran Ön test & 12 & 93.83 & 3.89 \\
& Şükran Son test & 12 & 95.91 & 4.92 \\
& Yaşam Doyumu Ön test & 12 & 19.08 & 2.25 \\
& Yaşam Doyumu Son test & 12 & 19.50 & 1.96 \\
\hline
\end{tabular}

Tablo 1'de deney ve kontrol gruplarının ön test ve son test ölçümleri sonucunda şükran ve yaşam doyumu ölçeklerinden aldıkları puanların ortalamaları gösterilmiştir. Tabloya göre deney grubunun şükran ölçeğinden aldığı ön test puan ortalaması (94.75), son test puan ortalaması (101.08), yaşam doyumu ölçeğinden aldığı ön test puan ortalaması (16.35), son test puan ortalaması (20.66) olarak ölçülmüştür. Kontrol grubunun ise şükran ölçeğinden aldığı ön test puan ortalaması (93.83), son test puan ortalaması (95.91), yaşam doyumu ölçeğinden aldığı ön test puan ortalaması (19.08), son test puan ortalaması (19.50) olarak ölçülmüştür. 
Tablo 2

Deney ve kontrol grubunun şükran ve yaşam doyumu ön-test puanları arasında anlamlı farklılığın olup olmadı̆̆ı belirlemek amacıyla yapılan Man Whitney-U Testi sonuçları

\begin{tabular}{lllllll}
\hline Puan & Grup & N & Sira Ort. & Sıra Toplamı & U & p \\
\hline \multirow{3}{*}{ Şükran } & Deney & 12 & 12.29 & 147.50 & 69.50 & .885 \\
& Kontrol & 12 & 12.71 & 152.50 & & \\
\hline \multirow{3}{*}{ Yaşam Doyumu } & Toplam & 24 & & & 61.00 & .522 \\
& Deney & 12 & 11.58 & 139 & & \\
\hline$p<.05$ & Kontrol & 12 & 13.42 & 161 & & \\
& Toplam & 24 & & & & \\
\end{tabular}

Tablo 2'ye göre deney ve kontrol grupları arasında şükran düzeyi ön test puanları $(U=$ $69.50, p>0.5)$ ve yaşam doyumu ön test puanları $(U=61.00, p>0.5)$ arasında anlamlı bir fark bulunmamıştır. $\mathrm{Bu}$ bulgulara göre uygulama aşamasına geçmeden önce deney ve kontrol gruplarının ön test sıra ortalamaları açısından aralarında anlamlı bir fark olmadığı ve istatistiksel olarak birbirlerine eşit olduğu söylenebilir.

\section{Tablo 3}

Kontrol grubu şükran ve yaşam doyumu ön test-son test puanları Wilcoxon İşaretli Siralar Testi analizi sonuçları

\begin{tabular}{llllll}
\hline & Ön test-Son test & N & Sira Ortalaması & Sira Toplamı & $\boldsymbol{p}$ \\
\hline \multirow{3}{*}{ Şükran } & Negatif Siralar & 3 & 4.67 & 14 & 0.313 \\
& Pozitif Sıralar & 6 & 5.17 & 31 & \\
& Fark Olmayan & 3 & & & 0.665 \\
& Toplam & 12 & & 33.50 & \\
& Negatif Siralar & 4 & 8.38 & 44.50 & \\
Yaşam Doyumu & Pozitif Siralar & 8 & 5.56 & & \\
& Fark Olmayan & 0 & & & \\
& Toplam & 12 & &
\end{tabular}

Tablo 3 incelendiğinde kontrol grubunun Şükran ön test-son test puanları $(\mathrm{z}=-1.009$; $p>.05)$ ve yaşam doyumu ön test-son test puan (z=-.433; $p>.05)$ ortalamaları arasındaki fark istatistiksel olarak anlamlı bulunmamıştır.

\section{Tablo 4}

Deney grubu şükran ve yaşam doyumu ön test-son test puanları Wilcoxon İşaretli Siralar Testi analizi sonuçları

\begin{tabular}{llllll}
\hline & Öntest-Sontest & N & Sıra Ortalaması & Sıra Toplamı & $\boldsymbol{p}$ \\
\hline \multirow{3}{*}{ Şükran } & Negatif Siralar & 4 & 3.13 & 12.50 & 0.06 \\
& Pozitif Sıralar & 7 & 7.64 & 53.50 & \\
& Fark Olmayan & 1 & & & 0.02 \\
\cline { 2 - 6 } Yaşam Doyumu & Toplam & 12 & & 7 & 59 \\
& Negatif Sıralar & 2 & 3.50 & & \\
& Pozitif Siralar & 9 & 6.56 & & \\
& Fark Olmayan & 1 & & & \\
\cline { 2 - 6 } & Toplam & 12 & &
\end{tabular}

Tablo 4' e incelendiğinde deney grubunun şükran puanları ön test-son test arasındaki fark puanları anlamlı bir şekilde farklılaşmazken ( $\mathrm{z}=-1.824 ; p>.05)$ yaşam doyumu puanlarının ön 
test-son test arasındaki fark puanlarının anlamlı düzeyde farklılaştığı bulunmuştur ( $\mathrm{z}=-2.02$; $\mathrm{p}=0.02$ ). Bu sonuca göre uygulanan müdahale programının deney grubundaki öğrencilerin yaşam doyumu düzeyinin artışında etkili olduğu söylenebilir.

\section{Tablo 5}

Deney ve kontrol grubunun şükran ve yaşam doyumu son-test puanları arasında anlamlı farklılığın olup olmadığı belirlemek amacıyla yapılan Mann Whitney-U Testi sonuçları

\begin{tabular}{lllllll}
\hline Puan & Grup & N & Sira Ort. & Sira Toplamı & U & $\boldsymbol{p}$ \\
\hline \multirow{3}{*}{ Şükran } & Deney & 12 & 13.29 & 159.50 & 62.50 & .583 \\
& Kontrol & 12 & 11.71 & 140.50 & & \\
\cline { 2 - 7 } & Toplam & 24 & & & 62.50 & .582 \\
\multirow{3}{*}{ Yaşam Doyumu } & Deney & 12 & 13.29 & 159.50 & & \\
& Kontrol & 12 & 11.71 & 140.50 & & \\
\cline { 2 - 7 } & Toplam & 24 & & & & \\
\hline$p<.05$ & & &
\end{tabular}

Tablo 5 incelendiğinde deney ve kontrol gruplarının șükran düzeyi son test (U:62.50, $p>0.5$ ) ve yaşam doyumu son test (U:62.50, $p>0.5$ ) puanları arasında anlamlı bir farklılaşma olmadığı görülmüștür.

\section{TARTIŞMA, SONUÇ VE ÖNERÍLER}

Araştırmada deney grubu öğrencilerine altı haftalık müdahale programı uygulanırken kontrol grubu öğrencilerine herhangi işlem yapılmamıştır. Araştırma kapsamında geliştirilen müdahale programının öğrencilerin yaşam doyumu ve şükran düzeylerini arttıracağı hipotezleri oluşturulmuştur. Yapılan çalışma sonucunda ulaşılan bulgulara göre, hazırlanan müdahale programının deney grubundaki öğrencilerin yaşam doyumu düzeyini anlamlı bir şekilde arttırdığı bulunurken şükran düzeylerinde meydana gelen yükselişin istatistiksel olarak anlamlı bir farklılık oluşturmadığı bulunmuştur.

Araştırmanın birinci bulgusunda hazırlanan müdahale programının deney grubunda yer alan öğrencilerin yaşam doyumu düzeyleri üzerinde etkili olduğu bulunmuştur. Buna göre öğrencilere uygulanacak sistematik bir programla onların yaşam doyumu düzeylerinin arttırılması mümkün görülmektedir. Uygulanan müdahale programının içeriğinde ilham verici hayat hikayelerinin paylaşılması, örnek filmlerin izlenmesi ve analiz dilmesi, çevrede rol model olabilecek insanlara ulaşma ve onlarla görüşmeler yapma gibi çeşitli müdahaleler yer almıştır. Ortaya çıkan sonuç bu yöntemlerin öğrencilerin yaşam doyumlarını arttırdığını ortaya koymaktadır. Alanyazın incelendiğinde ergenlerde yaşam doyumu düzeyini artırmaya yönelik deneysel müdahale programlarının sınırlı olduğu görülmüştür. Bu çalışmadan elde edilen sonuçların alanyazında ergenlerde yaşam doyumunu arttırmaya yönelik yapılan diğer çalışmalar (Eryllmaz, 2012; Özbiçer-Mavruk, 2018; Raj vd., 2019; Suldo vd., 2014) ile paralel sonuçlara ulaşıldığı görülmüştür. Alanyazın incelendiğinde yaşam doyumunun ergenlerde akademik başarı 
(Hg vd., 2020), madde kullanımının önlenmesi (Zullig vd., 2001), okulda şiddet davranışı (Varela vd., 2018), okula bağlılık (Çakar ve Karataş, 2017), ebeveyne bağlanma (Özgüngör, 2020), kariyer uyumu (Bölükbaşı ve Kırdök, 2019), iyimserlik ve akademik başarı (Erdoğdu, 2020), iyi oluş (Şahin, 2019) değiş̧kenleri üzerinde etkili olduğu görülmüştür. Bu sonuçlar dikkate alındığında okullarda öğrenciler arasında yaşam doyumunu arttırıcı faaliyetlerin yaygınlaştırılması önemlidir. Bu durum hem doğrudan öğrencilerin yaşam doyumu düzeylerini arttırabilmekte, hem de dolaylı olarak çeşitli alanlarda onlara önemli kazanımlar sağlamaktadır. Bu durum bir yandan pozitif psikoloji yaklaşımı, diğer yandan 21. yüz yılın rehberlik anlayışını ifade eden "gelişimsel rehberlik modeli" ile de uyumludur. Buna göre okullarda herhangi bir sorun ya da kriz durumu olmadan, gelişimsel anlayışla öğrencilere zamanında çeşitli beceri, tutum ve anlayışlar kazandırmak önemlidir. Bu yaklaşım öğrencilerin genel yaşam doyumunu ve okul iyi oluş düzeylerini arttıracak ve onları çeşitli sorun alanlarından uzak tutacaktır. Sonuç olarak pozitif psikoloji temelli müdahale programlarının çeşitlendirilmesinin ve yaygınlaştırılmasının önemli olduğu söylenebilir.

Pozitif psikolojinin etkisi ile bireylerin yalnızca olumsuz, eksik, yetersiz, bozuk yönlerine odaklanılmaması, güçlü yönlerin, pozitif duyguların ve karakter güçlerinin de vurgulanması gerektiği anlaşılmış ve bireylerin yaygın olarak yaşadığı pozitif bir duygu olan şükran kavramı çalışılan bir kavram haline gelmiştir. Bu durum şükran ile ilgili kuramsal yapıların geliştirilmesi ve bu kuramsal yapılar çerçevesinde müdahale programlarının hazırlanması ve uygulanmasını sağlamıştır (Kardaş ve Yalçın, 2018). Yapılan araştırma kapsamında deney grubuna uygulanan müdahale programı sonucunda öğrencilerin şükran düzeylerinde olumlu anlamda artış görüldüğü ancak bu artışın istatistiksel olarak anlamlı olmadığı bulunmuştur. Bu sonuç, uygulanan müdahale programının şükran düzeyinde uygulanan etkinliklerin azlığı, sürenin sınırlı olması, çalışma grubunun özellikleri ve uygulayıcının yeterliliği ile ilgili sınırlılıklardan kaynaklanmış olabilir. Buna göre bundan sonraki benzer müdahale çalışmalarında doğrudan şükran duygusunu geliştirmeye yönelik etkinliklerin sayısının arttırılması, müdahale süresinin uzatılması ve çalışma grubunun gelişimsel ihtiyaçlarının göz önünde bulundurulması yararlı olacaktır. Diğer yandan, çalışmada şükran duyma düzeyinde anlamlı bir artış meydana gelmese de katılımcıların yaşam doyumu düzeyinin arttı̆̆ belirlenmiştir. Bu durum şükran duymaya ilişkin müdahalelerin yaşam doyumunu arttırmaya anlamlı katkı sunduğunu ortaya koymaktadır. Buradan hareketle şükran müdahalelerinin çeşitli açılardan yararlı olduğu ancak şükran duymayı arttırmaya yönelik çalışmalar için daha farklı müdahale yöntemlerinin belirlenmesi gerektiği sonucuna ulaşılabilir. Bu da her şeyden önce kültüre özgü ve müdahalenin uygulanacağı kitlenin gelişimsel ihtiyaçlarına uygun yeni yöntemlerin geliştirilmesi gerektiğine işaret etmektedir. 
Alanyazın incelendiğinde şükran düzeyini arttırmaya yönelik deneysel çalışmaların çok sınırlı olduğu görülmüştür. Yurt içinde yapılan çalışmalar incelendiğinde Teoman (2015) tarafından yapılan çalışmada şükran müdahalesinin katılımcıların uygulama sonrasında ölçülen şükran duyma düzeylerini artırarak iyimser başa çıkma tarzını güçlendirdiği bulunmuştur. Benzer şekilde yurt dışında Heckendorf ve arkadaşları (2019) tarafından yapılan çalışmada da şükran temelli müdahale programının tekrarlayan olumsuz düşüncelerin azalmasını sağladığı bulunmuştur. Ergen bireylerde şükran düzeyi ile ilgili alan yazın incelendiğinde şükran düzeyinin ergenlerde yaşam doyumu ve yaşam amaçları (Sezer ve Turğut, 2019), iyi oluş (Altıntaş, 2018), öğrenme katılımı (Jin ve Wang, 2019), akıl sağlığı (Duprey vd., 2020) ve travma sonrası büyüme (Zhou ve Wu, 2016) gibi değişkenler üzerinde etkili olduğu bulunmuştur. Sonuç olarak okullarda şükran müdahale programlarının uygulanması öğrencilerin duygusal zorluklarla başa çıkmasına yardımcı olabilir.

Pozitif psikoloji yaklaşımını destekleyen ampirik bulgular çoğaldıkça, bu yaklaşımın eğitimde ve diğer kurumsal alanlarda da kullanılması yaygınlaşacaktır (Güngör, 2017). Bu araştırma kapsamında hazırlanan müdahale programında 11. sınıfa devam eden lise öğrencilerinin yaşam doyumu düzeyindeki artış istatistiksel olarak anlamlı bulunurken şükran düzeyinde artış görülmediği söylenebilir. Bu bakımdan hazırlanan müdahale programının okul psikolojik danışma ve rehberlik hizmetlerinin önemli bir parçası olan önleyici ve geliştirici müdahalelerin geliştirilmesi ve uygulanması açısından önemlidir. Ancak bu çalışma kendi içinde bazı sınırlılıklar barındırmaktadır. Hazırlanan müdahale programının 6 oturum olması, müdahale programını uygulayanın yetkinliği ile sınırlı olması, sadece 11. sınıf öğrencilerinin olması gibi sınırlılıklar barındırmaktadır. Yöntemsel olarak parametrik olmayan testlerin ve yarı deneysel desenin kullanılması da çalışmanın sınırlılıklarındandır. $\mathrm{Bu}$ bakımdan bundan sonraki çalışmalarda bu sınırlılıkların göz önünde bulundurularak düzenlenmesi daha güçlü çalışmaların ortaya çıkmasını sağlayacaktır. 


\section{KAYNAKÇA}

Altuntaş, (2018). Ergenlerde iyi oluşun yordayıcısı olarak yaşamda anlam, minnettarlık ve affedicilik [Yayımlanmamış Doktora Tezi]. İnönü Üniversitesi.

Bölükbaşı, A., \& Kırdök, O. (2019). Lise öğrencilerinin kariyer uyumu ve yaşam doyumu ilişkisinde gelecek yöneliminin aracı rolü. Eğitim ve Bilim Dergisi, 44 (200), 77-91. http://dx.doi.org/10.15390/EB.2019.8090

Büyüköztürk, Ş. (2017). Sosyal bilimler için veri analizi el kitabı (23. Basım). Pegem Yayınları.

Büyüköztürk, Ş., Kılıç Çakmak, E., Akgün, E. A., Karadeniz, Ş., \& Demirel, F. (2018). Bilimsel araştırma yöntemleri (25.Basım). Pegem Yayıncılık.

Can, A. (2019). SPSS ile bilimsel araștırma sürecinde nicel veri analizi (8. Baskı). Pegem Yayıncılık. Çivitci, A. (2020). Grup Psiko-eğitimi (3. Basım). Pegem Yayınları.

Çivitçi, A. (2012). Üniversite öğrencilerinde genel yaşam doyumu ve psikolojik ihtiyaçlar arasındaki ilişkiler. Çukurova Üniversitesi Sosyal Bilimler Enstitüsü Dergisi, 21(2), 321336.

Dağll, A., \& Baysal, N. (2016). Yaşam Doyumu Ölçeği'nin Türkçeye uyarlanması: Geçerlilik ve güvenirlik çalışması. Elektronik Sosyal Bilimler Dergisi, 15(59), 1250-1262. https://doi.org/10.17755/esosder.263229

Diener, E. (2000). Subjective well-being: The science of happiness and a proposal for a national index. American Psychologist, 55, 1, 34-43.

Diener, E., Emmons, R. A., Larsen, R. J., \& Griffin, S. (1985). The Satisfaction With Life Scale. Journal of Personality Assessment, 49 (1), 71-75.

Diener, E., Oishi, S., \& Tay, L. (2018). Advances in subjective well-being research. Nature Human Behaviour, 2 (4), 253-260. https://doi.org/10.1038/s41562-018-0307-6

Diener, E., Sulh, F. M., Lucas, R. E., \& Smith, H. L. (1999). Subjective well-being: Three decades of progress. Psychological Bulletin, 125 (2), 276-302.

Duprey, E. B., Mckee, L. G., O’Neal, C. W., Algoe, S. B., \& Campos, B. (2020). Stressors, resources, and mental health among Latino adolescents: The role of gratitude. Journal of Applied DevelopmentalPsychology. https://doi.org/10.1016/j.appdev.2020.101191

Erdoğdu, M. Y. (2020). İyimserlik (yaşam yönelimi) ile yaşam doyumu arasındaki ilişkide akademik başarının aracılık rolü. Eğitim ve Bilim Dergisi, Erken Görünüm, 1-13. http://dx.doi.org/10.15390/EB.2020.8998

Ergüner-Tekinalp, B., \& Işık, Ş. (2020). Eğitimde pozitif psikoloji uygulamaları (4. Basım). Pegem Yayınları.

Erol, M. (2017). Genç yetişkinliğin öncesinde olan ergenlerin yaşam doyumu: "utangaçlık" ve "öz yeterlik" algısının rolü. Türk Psikiyatri Dergisi, 28(2), 95-103.

Eryılmaz, A. (2012). Pozitif psikoterapi bağlamında geliştirilen ergenler için amaçları genişletme grup rehberliği programının etkililiğinin incelenmesi. Eğitim ve Bilim, 37 (164), 3-19.

Froh, J. J., Sefick, W. J., \& Emmons, R. A. (2008). Counting blessings in early adolescents: An experimental study of gratitude and subjective well-being. Journal of School Psychology, 46 (2), 213-233. https://doi.org/10.1016/j.jsp.2007.03.005

Froh, J. J., Yurkewicz, C. ve Kashdan, T. B. (2009). Gratitude and subjective well-being in early adolescence: Examining gender differences. Journal of Adolescence, 32(3), 633-650. https://doi.org/10.1016/j.adolescence.2008.06.006

Güngör, A. (2017). Eğitimde pozitif psikolojiyi anlamak. Türk Eğitim Dergisi, 15(2), 154-166.

Heckendorf, H., Lehr, D., Ebert, D. D., \& Freund, H. (2019). Efficacy of an internet and app-based gratitude intervention in reducing repetitive negative thinking and mechanisms of change 
in the intervention's effect on anxiety and depression: results from a randomized controlled trial. Behaviour Research and Therapy, 119, 103415. https://doi.org/10.1016/j.brat.2019.103415

Hefferon, K., \& Boniwell, I. (2014). Positive psychology: Theory, research and applications. McGraw-Hill Education (UK).

Jin, G., \& Wang, Y. (2019). The influence of gratitude on learning engagement among adolescents: The multiple mediating effects of teachers' emotional support and students' basic psychological needs. Journal of Adolescence, 77, 21-31. https://doi.org/10.1016/j.adolescence.2019.09.006

Karasar, N. (2014). Bilimsel araștırma yöntemi (26. Basım). Nobel Yayıncılık.

Kardaş, F. ve Yalçın, İ. (2020). The Broaden-and-Built Theory of Gratitude: Testing a model of wellbeing and resilience on Turkish college students. Participatory Educational Research, 8(1), 141-159. https://doi.org/10.17275/per.21.8.8.1

Kardaş, F., \& Yalçın, İ. (2018). Şükran: Ruh sağlığı alanında güncel bir kavram. Psikiyatride Güncel Yaklaşımlar, 10 (1), 1-18. https://dx.doi.org/10.18863/pgy.334494

Kardaş, F., \& Yalçın, İ. (2019). Şükran Ölçeği'nin geliştirilmesi: Geçerlilik ve güvenirlik çalışması. $\begin{array}{llllll}\text { Elektronik } & \text { Sosyal } & \text { Bilimler } & \text { Dergisi, } & 18 & \text { (69), }\end{array}$ https://doi.org/10.17755/esosder.406306

Köse, N. (2016). Ergenlerde internet bağımlılığının yaşam doyumuna etkisi. Elektronik Mesleki Gelişim ve Araştırmalar Dergisi, 4 (1), 15-23.

Ma, M., Kibler, J. L. ve Sly, K. (2013). Gratitude is associated with greater levels of protective factors and lower levels of risks in africa namerican adolescents. Journal of Adolescence, 36 (5), 983-991. https://doi.org/10.1016/j.adolescence.2013.07.012

Malkoç, A. (2011). Öznel iyi oluş müdahale programının üniversite öğrencilerinin öznel iyi oluş düzeylerine etkisi [Yayımlanmamıș Doktora Tezi]. Marmara Üniversitesi.

Ng, Z. J., Huebner, S. E. ve Hills, K. J. (2015). Life satisfaction and academic performance in early adolescents: Evidence for reciprocal association. Journal of School Psychology, 53, 479491. https://doi.org/10.1016/j.jsp.2015.09.004

Özbiçer-Mavruk, S. (2018). Duygusal zekâ geliştirme programının ergenlerin duygusal zeka ve yaşam doyumu düzeylerine etkisi: Deneysel bir çalışma [Yayımlanmamış Doktora Tezi]. Çukurova Üniversitesi.

Özdemir, Y. ve Sağkal, A. S. (2016). Ergenler İçin Kısa Okulda Öznel İyi Oluş Ölçeğinin Türkçe' ye Uyarlanması: Geçerlik ve Güvenirlik Çalışması. Ege Eğitim Dergisi, 17(2), 333-350. DOI: 10.12984/egeefd.280748

Özgüngör, S. (2020). Ergenlerde anneye ve babaya bağlanma ile başarı yönelimleri ve yaşam doyumu arasındaki ilişkilerin incelenmesi. Eğitim ve Bilim, 45 (203), 253-273. http://dx.doi.org/10.15390/EB.2020.8697

Özgür, G., Gümüş, A. B., \& Durdu, B. (2010), Evde ve yurtta kalan üniversite öğrencilerinde yaşam doyumu. Psikiyatri Hemşireliği Dergisi, 1(1), 25-32.

Proctor, C., Linley, P., \& Maltby, J. (2009). Youth life satisfaction: A review of the literature. Journal of Happiness Studies, 10, 583-630. https://doi.org/10.1007/s10902-008-9110-9

Raj, S., Sachdeva, S. A., Jha, R., Sharad, S., Singh, T., Arya, Y. K. ve Verma, S. K. (2019). Effectiveness of mindfulness based cognitive behavior therapy on life satisfaction, and life orientation of adolescents with depression and suicidal ideation. Asian Journal of Psychiatry, 39, 5862. https://doi.org/10.1016/j.ajp.2018.12.001

Ryff, C. D. (1989). Happiness is everything, or is it? Explorations on the meaning of psychological well-being. Journal of Personality and Social Psychology, 57 (6), 1069-1081. 
Ryff, C. D., \& Keyes, C. L. M. (1995). The structure of psychological well-being revisited. Journal of Personality and Social Psychology, 69 (4), 719-727.

Savi-Çakar, F., \& Karataş, Z. (2017). Ergenlerin okula bağlanmalarının yordayıcıları olarak benlik saygısı, okul öfkesi ve yaşam doyumu. Eğitim ve Bilim Dergisi, 42(189), 121-136. http://dx.doi.org/10.15390/EB.2017.6573

Seligman, M. P., \& Csikszentmihalyi, M. (2000). Positivepsychology: An introduction. American Psychologist, 55 (1), 5-14. https://doi.org/10.1007/978-94-017-9088-8_18

Sezer, Ö., \& Turğut, E. (2019). Ergenlerde şükran, yaşam amaçları ve yaşam doyumunun bazı değişkenler açısından incelenmesi. YYÜ Eğitim Fakültesi Dergisi, 16 (1), 1463-1491. https://doi.org/10.33711/yyuefd.660501

Suldo, S. M., Savage, J. A. ve Mercer, S. H. (2014). Increasing middle school students' life satisfaction: Efficacy of a positive psychology group intervention. Journal of Happiness Study, 15, 19-42. https://doi.org/10.1007/s10902-013-9414-2

Şahin, A. (2019). Üniversite öğrencilerinde bilinçli farkındalık ile yaşam doyumu ve iyi oluş arasındaki ilişkiler. Üsküdar Üniversitesi Sosyal Bilimler Dergisi, 8, 151-176. https://doi.org/10.32739/uskudarsbd.5.8.61

Şirin, A., \& Ulaş, E. (2015). Ortaokul öğrencilerinin öznel iyi oluş düzeyleri ile karakter eğitimi uygulamaları arasındaki ilişkinin incelenmesi. Değerler Eğitimi Dergisi, 12 (30), 279-307.

Teoman, D. D. (2015). Bir pozitif psikoloji uygulama örneği olarak şükran müdahalesi ile çalışanların dayanıklılıklarını arttırmaya ve stresle başa çıkma tarzlarını iyileştirmeye yönelik bir alan çalışması [Yayımlanmamış Doktora Tezi]. İstanbul Üniversitesi

Türkel, Z., \& Dilmaç, B. (2019). Ergenlerde sosyal medya kullanımı, yalnızlık ve yaşam doyumu arasındaki yordayıcı ilişkiler. Necmettin Erbakan Üniversitesi Ereğli Eğitim Fakültesi Dergisi, 1 (1), 57-70.

Varela, J. J., Zimmerman, M. A., Ryan, A. M., Stoddard, S. A., Heinze, J. E., \& Alfaro, J. (2017). Life satisfaction, school satisfaction, and school violence: A mediation analysis for chilean adolescent victims and perpetrators. Child Indicators Research, 11, 487-505. https://doi.org/10.1007/s12187-016-9442-7

Zhou, X., \& Wu, X. (2016). Understanding the roles of gratitude and social support in posttraumatic growth among adolescents after Ya'an earthquake: A longitudinal study. Personality and Individual Differences, 101, 4-8. https://doi.org/10.1016/j.paid.2016.05.033

Zullig, K. J., Valois, R. F., Huebner, E. S., Oeltman, J. E. ve Drane, J. W. (2001). Relationship between perceived life satisfaction and adolescents' substance abuse. Journal of Adolescent Health, 29, 279-288. https://doi.org/10.1016/S1054-139X(01)00269-5 


\section{EXTENDED ABSTRACT}

\section{Introduction}

As an important development environment, school is an important place where students both spend most of their time (Özdemir-Sağkal, 2013) and gain cognitive, social and emotional skills (Güngör, 2017). The aim of the schools is to train individuals as people who will contribute to the society and the world in which they live. In this context, in addition to acquiring academic skills and the teaching process, it is also important to gain and strengthen character strengths that will increase well-being, and this comprehensive approach is expected to better prepare students for life(Ergüner-Tekinalp, 2020). Despite the problem-oriented perspective of traditional psychology (Şirin-Ulaş, 2015), positive psychology, which is a relatively new approach, argues that focusing on the positive characters of individuals will increase their quality of life and develop their potential (Güngör, 2017). Seligman and Csikszentmihalyi (2000), who have important studies in this field, argue that educators and psychologists should work to increase people's wellbeing levels.

\section{Method}

This study is a quasi-experimental research aiming to determine the effect of an intervention program designed to increase the gratitude and life satisfaction levels of secondary school students. In the research, a split-plot design with two factors $(2 \times 2)$ with pretest-posttest control group has been used. Quasi-experimental models are used in cases where the controls required by real experimental models cannot be achieved (Karasar, 2014). The sample has consisted of 24 (12 for the experimental group and 12 for the control group) adolescent who are high school students. The intervention program has taken place in 6 sessions of 90 minutes. Life Satisfaction Scale and Gratitude Scale has been used to collect data. While a six-week intervention program has been applied to the experimental group, no application has been made to the control group.

\section{Results}

In this section, the effect of the intervention program developed by the researchers on the variables of life satisfaction and gratitude level has been discussed. While the six-week intervention program has been applied to the experimental group students in the study, no action has been taken against the control group students. It has been hypothesized that the intervention program developed within the scope of the research will increase the life satisfaction and gratitude levels of the students. According to the findings obtained as a result of the study, it has been found that the prepared intervention program significantly increases the level of life 
satisfaction of the students in the experimental group, while the increase in gratitude does not create a statistically significant difference.

\section{Discussion \& Conclusion}

As the evidence supporting positive psychology increases, the use of positive psychology in education and other institutional areas will increase (Güngör, 2017). As a matter of fact, Terjesen et al. (2004) have stated that encouraging positive traits may be more effective than curing problems. In the intervention program prepared within the scope of this research, it can be said that while the life satisfaction of the 11th grade high school students is found to be statistically significant, there is no increase in the level of gratitude. In this respect, the prepared intervention program is important in terms of developing and implementing preventive and improving interventions, which are an important part of school psychological counseling and guidance services. However, this study has some limitations in itself. It has limitations such as the intervention program prepared for 6 sessions, being limited to the competence of the person applying the intervention program, and only 11th grade students. Methodologically, the use of non-parametric tests and quasi-experimental design are also limitations of the study. In this respect, future studies should be organized by taking these limitations into consideration, which will lead to stronger studies. 